\title{
Встреча людей Средневековья на пороге века Просвещения (князь Куракин и герцог Сен-Симон) ${ }^{1}$
}

\author{
Ю.М. Эскин \\ Российский государственный архив древних актов (Москва) \\ eskin@post.ru
}

\begin{abstract}
:
"A Meeting Between Two Medieval Men on the Doorstep of the Enlightened Age: Prince Kurakin and the Duc de Saint-Simon"

This article reconstructs the cultural context surrounding the meeting between a well-born Russian servitor (Prince B. I. Kurakin) and a French aristocrat (Louis de Rouvroy, duc de Saint-Simon). As the author demonstrates, notwithstanding their different backgrounds and experiences, these two representatives of the ancien régime shared many things in common, including an avid interest in noble genealogy, honor, and life-writing. These commonly-shared interests formed the basis of a mutually-beneficial relationship, and may even have informed their political and literary activity.
\end{abstract}

Keywords:

Prince B. I. Kurakin; Louis de Rouvroy, duc de Saint-Simon; Russo-French relations; nobility; codes of honor; life-writing

На исходе первой четверти XVIII в. в Париже познакомились два человека, русский и француз, имевшие в своей судьбе на первый взгляд немало общего. Они были почти ровесниками, носили княжеский титул, воспитывались при дворе, в молодости служили в гвардии и воевали, а к моменту знакомства уже были дипломатами в ранге послов. Оба оставили интереснейшее мемуарноисторическое наследие, но труд француза много обширнее, поскольку он пережил русского на 25 лет. А к писанию на основе более ранних дневниковых записей они приступили примерно в одно время, приблизительно в период возникновения знакомства. Сочинения обоих не оказали влияния на современников, поскольку были опубликованы много позднее, в иные эпохи, когда уже представляли интерес сугубо исторический. Однако точные характеристики, уникальные факты делают их творческое наследие ценнейшим

\footnotetext{
1 Работа эта была написана более 20 лет назад для сборника статей ИРИ РАН Человек Средневековья и Раннего Нового времени, готовившегося покойной д. и. н. Е. И. Колычевой, по чьей инициативе автор и подготовил это исследование. По ряду причин (финансовые проблемы, смерть Колычевой) сборник на запоздало входившую тогда в моду в постсоветской историографии "антропологическую" тему был собран, но не издан, и авторы постепенно забрали и опубликовали статьи в других изданиях. Автор данной работы не прилагал усилий для ее публикации отчасти из-за того, что полагает себя недостаточно компетентным в тематике XVIII в., а отчасти ввиду занятий своей темой - местничеством XVI- XVII вв., некоторые методы изучения которого он и применил в исследованном в статье вопросе. Однако с этой работой на протяжении указанного времени знакомились специалисты по русскому менталитету XVIII в. (O. Е. Кошелева, Е. Н. Марасинова, Э. А. Зицер), которые и убедили автора ее опубликовать. Автор должен предупредить читателей, что статья эта выглядит архаично, являясь фактом историографии начала 1990-х гг. (более новые отечественные и зарубежные работы в ней не использованы, даже академическое издание Сен-Симона), и представляет вероятно интерес как опыт "взгляда со стороны" - историка периода XVI- XVII вв. на проблемы более позднего, переходного времени.
} 
историческим источником для обеих стран. Успеху сочинений, возможно, способствовала одна и та же черта - некоторая отстраненность, изобличающая тот факт, что оба историка-мемуариста сами, как личности, были несколько чужими в своем времени. Это были князь Борис Иванович Куракин, посол России при Версальском дворе, и Луи де Рувруа, герцог де Сен-Симон, пэр Франции.

Князь Куракин родился в 1676 г. в Москве, он был сыном боярина и крестником царя Федора Алексеевича. Сен-Симон родился в 1675 г. в Париже, был сыном пэра и крестником Людовика XIV. Оба в детстве были хилыми и некрасивыми, но Сен-Симон дожил до 8о лет, а Куракина то ли болезни, то ли отечественные и западноевропейские медики свели в могилу в 52 года. Оба рано начали военную службу и совершили несколько походов: Куракин в числе стольников и в Семеновском полку, Сен-Симон - в королевских мушкетерах. Оба не были в фаворе. Куракин был на четыре года моложе Петра, поэтому не мог стать товарищем его детских игр, а в дальнейшем слабое здоровье мешало достойно сопутствовать царю в бесконечных походах, поездках и в разгуле в часы досуга. Ранняя женитьба на сестре царицы Евдокии вопреки надеждам устроившей брак родни обернулась дополнительными осложнениями в отношениях с Петром. "Кабинетный" характер князя, частые болезни, склонность к дипломатической, а не военной деятельности вызывали раздражение и гнев экспансивного царя. После одного такого жестокого разноса Куракин, видимо, получил нервное потрясение: “с той поры потерял я память, рассудок, здоровье, [...] стал тревожиться по всяким пустякам, постоянно чувствовать себя в состоянии меланхолии и душевного расстройства.” А Сен-Симон в глазах Людовика XIV был чванливым мальчишкой, который не только оставил военную службу после того, как его раз обошли в чине, но и осмеливался подавать проекты о восстановлении и провозглашении незыблемыми разных аристократических привилегий.

Имелись в их судьбах и существенные различия. Так, Сен-Симон был очень счастлив в браке, а семейная жизнь Куракина не задалась: первая жена рано умерла, а отношения со второй были таковы, что он не раз подумывал о разводе. ${ }^{3}$ Напротив, если Сен-Симон практически не сделал карьеры, почти всю жизнь оставаясь при дворе без должностей, то в послужном списке Куракина посольства с важнейшими миссиями в Рим, Вену, Ганновер, участие в Аландском и Утрехтском конгрессах, многолетнее представительство России в ранге полномочного посла в Англии и Франции, координация всей русской внешней политики в Западной Европе. Он не наблюдатель, как Сен-Симон, а участник и вершитель истории; но венца дипломатической карьеры - канцлерского поста так и не достиг: принципиальному, независимому в суждениях и архикомпетентному Куракину Петр предпочитал посредственного, но понятного и верного Г.И. Головкина. ${ }^{4}$ Иным было отношение его зарубежных коллег -

\footnotetext{
2 “Семейная хроника и воспоминания князя Б.И. Куракина," Киевская старина [далее: Киевская старина] 12 (1884), 628.

${ }^{3}$ Киевская старина 11 (1884), 493-494.

${ }^{4}$ См. Н.Н. Молчанов, Дипломатия Петра I (М., 1984), 368: “Донесения и письма Куракина [...] поразительны по глубине мысли, обоснованности предлагаемых решений [...] Повинуясь своему долгу [...] Куракин выполнял любое, даже неправильное по его мнению указание, но при этом
} 
партнеров и противников. Французский двор считал, что Куракин - “самый благовоспитанный и одаренный из русских представителей, и его образ действий всегда прямой."5 Амбиции Сен-Симона тоже не были удовлетворены. Его ум и знания ценили дофин и Филипп Орлеанский; но первый умер, а второй, став регентом не имел воли следовать мудрым советам (эпоха его правления вошла в историю как символ легкомыслия).

Когда могли познакомиться Сен-Симон и Куракин? Возможно, это произошло в мае-июне 1717 г., когда князь сопровождал Петра I во Францию, вел переговоры (вместе с П.П.Шафировым) о посредничестве в мире со Швецией, а во время получасовых переговоров царя с регентом в Тюильри 17 июня 1717 г. переводил, ${ }^{6}$ стоя меж их креслами. Для Сен-Симона Петр был неким античным или экзотическим героем, на чьи подвиги в борьбе с "варварством" в своей стране и на поле брани “Франция взирала как на чудо и была очарована." Он стремился побольше узнать и оставил интересные страницы мемуаров о пребывании Петра в Париже, в числе многих любопытных придворных посещал те же места, что и царь, и, вероятно, стремился познакомиться с теми, кто его хорошо знал. Возможно, таковы причины его знакомства с Куракиным. Но произошло ли оно уже тогда или только в 1724 г., когда князь стал послом в Париже, неясно. ${ }^{7}$ Известно, что Сен-Симон участвовал в 1717 г. в совещании у регента по вопросу приема царя. ${ }^{8}$ Возможно, он как признанный знаток версальского этикета консультировал Куракина, который тщательно собирал информацию о придворном и посольском церемониале в Амстердаме, Вене, Лондоне, Ганновере, Риме. Знакомство могло быть полезно обоим - каждый нашел не только “равного” по титулу и происхождению, но и обладавшего большой культурой собеседника. ${ }^{9}$ Главное же состояло в том, что они оказались во многом единомышленниками. "Я обедал у него, он обедал у меня, я много беседовал с ним и с большим удовольствием слушал его разговоры на самые разные темы” - сообщает Сен-Симон. ${ }^{10}$ Характеристика русского посла у СенСимона столь же благожелательна, как и характеристика монарха: “Он был высок, хорошо сложен, понимал высоту своего происхождения, обладал большим умом, хитростью и был весьма образован." мечалось, что Парижу “импонировала фигура Куракина,” который, по словам испанского дипломата Гримальдо, “был человеком самого изысканного

старался тактично переубедить Петра."

${ }^{5}$ С.А. Фейгина, Аландский конгресс (М.. 1959), 130.

${ }^{6}$ Фейгина, Аландский конгресс, 142; Сен-Симон [Louis de Rouvroy, duc de Saint-Simon], Mемуары. Полные и доподлинные воспоминания герцога де Сен-Симона о веке Людовика XIV и регентстве. Избранные главы (М., 1991) [далее: Сен-Симон, Мемуары], Т. 2: 360, 370, 372.

${ }^{7}$ По некоторым деталям Мемуаров можно предположить, что они могли быть знакомы уже во время визита. Сен-Симон отмечает например, что Куракин каждый день приезжал к Петру в его резиденцию, дворец Лесдигьер, но жил у себя; что Куракин переводил беседы царя с регентом и королем. См. Сен-Симон, Мемуары, Т. 2: 352, 360, 370, 372.

${ }^{8}$ Ibid., 349 .

9 Молчанов, Дипломатия Петра I, 368 отмечает, что Куракин был как бы “самым интеллигентным из петровских дипломатов” и к нему наиболее применима формулировка Г. Никольсена о том, что совершеннейший тип дипломата - это "рассудительный и гуманный скептик."

${ }^{10}$ Сен-Симон, Мемуары, 354.

${ }^{11}$ Ibid., 350-351. 
обращения"; не зря Петр предпочел воспользоваться в переговорах с Францией им, а не оставленным в Амстердаме Головкиным, ибо здесь требовались находчивость, смелость в решениях и личные связи. ${ }^{12}$ Встречи Сен-Симона и Куракина продолжались не менее трех лет, вплоть до смерти князя на посту посла в Париже 17 октября 1727 г. Сен-Симон обнаружил в Куракине интереснейший источник информации о России (некоторые сведения о которой, правда, в его мемуарах изрядно перепутаны). Возможно, он не все понимал правильно в рассказах Куракина, или впоследствии его подвела память при написании мемуаров. Так, Куракин поведал ему, что нынешняя династия Романовы - принадлежит к “обычной русской аристократии," что было весьма многозначительно в устах князя, принадлежащего “к одной из ветвей рода Ягеллонов,” как с удовольствием отмечает Сен-Симон. ${ }^{13}$ Из рассказов о Филарете и патриаршестве Сен-Симон сделал фантастический вывод, что Романовы были чем-то вроде наследственных патриархов, и лишь отец Петра стал первым царем в династии. ${ }^{14}$ Известные хлопоты богословов Сорбонны перед Петром о соединении церквей ${ }^{15}$ побудили Куракина к воспоминаниям о своей миссии в Рим, где он, оказывается, помимо прочих заданий, изучал и этот вопрос, и о том, как прочитавший его обстоятельный отчет Петр, вздохнув, заметил, что не желает опять иметь над собой начальника. ${ }^{16}$ Сопутствовали хорошим отношениям и анти-английские настроения герцога, безуспешно ратовавшего за союз с Россией: "Потом пришлось долго раскаиваться, что мы поддались гибельным чарам Англии и так по-дурацки презрели Россию” - с некоторым злорадством отмечает Сен-Симон. ${ }^{17}$

Для того, чтобы понять, что составляло основу бесед Сен-Симона и Куракина, следует уяснить, в чем было отличие последнего от других русских дипломатов и мемуаристов того времени. Е.Ф. Шмурло считает, что Куракин относился к тем личностям петровской эпохи, которые восприняли с Запада не только “факты, не одно только познание внешнего мира, но и мысли, идеи, точки зрения.” 8 Достаточно сравнить его зарубежные впечатления с восприятием других тогдашних петровских посланцев - А.А.Матвеева, А.Л. и И.Л.Нарышкиных, П.А.Толстого.

Ошибочно было бы не учитывать и тот интеллектуально-психологический багаж, с которым Куракин впервые начал знакомиться с западноевропейской культурой. Его вышеперечисленные коллеги были “людьми неродословными”: близость их ко двору была вызвана цепью случайных обстоятельств (первыми

\footnotetext{
${ }^{12}$ Фейгина, Аландский конгресс, 133.

${ }^{13}$ Гедиминовичей именует Ягеллонами и Де ла Невилль (видимо, иностранцам так часто объясняли для простоты), упоминая о происхождении князя В.В.Голицына. См. Де ла Невилль [Foy de la Neufville], “Любопытные и новые известия о Московии," Россия XV-XVII вв. глазами иностранцев (Л., 1986), 512; O. Kosheleva, "Gediminacial rusijos bojarinu dumos sudetuje caru Aleksejaus ir Fiodoro valdymo metais," Lituanistica 1:5 (1991), 9.

${ }^{14}$ Сен-Симон, Мемуары, 352.

${ }^{15}$ П. Пекарский, Наука и литература в России при Петре Великом (СПб., 1862), 41.

${ }^{16}$ Сен-Симон, Мемуары, 352.

${ }^{17}$ Ibid., 374. Позиция его, однако, отличалась некоторой наивностью, поскольку для Франции много важнее тогда была поддержка Англии на Пиренеях и традиционные точки опоры в Восточной Европе: Швеция-Польша-Турция. См. Фейгина, Аландский конгресс, 145-146.

18 Е.Ф. Шмурло, “Новый свидетель преобразований,” Журнал Министерства народного просвещения 1 (1891), 200.
} 
боярами в роду были лишь отцы Матвеева и Нарышкиных, окольничим - дед Толстого). А князья Куракины веками находились в верхах русской аристократии, ощущая к тому же и свою принадлежность как Гедиминовичи - к правящей верхушке соседних держав. Аристократическое самосознание Куракина проступает во всех оставленных им сочинениях - записках для себя и официальных “мемуарах." Он “пристально следит за положением дворянства в Европе,” что в дальнейшем даст ему материал для сопоставления с прошлым и настоящим российского дворянства, считает А.Н.Котляров. ${ }^{19}$ Так, если П.А.Толстого в Венеции интересуют театры и карнавалы, то Куракин в заметках 1707 г. дает четкие характеристики разных слоев местного господствующего класса, особо отмечая разницу в правах венецианского и балканского дворянства. ${ }^{20}$ “Высота происхождения” для Куракина действительно важнейшая ценность, и зарубежные впечатления укрепляют его мировоззрение. Находясь в разных странах Европы, он не только ревностно следит за соблюдением дипломатического и придворного этикета, но и обнаруживает, что принадлежит к особам, которым оказываются персональные почести, связанные с княжеским титулом, что было не характерно для России. Описывая прием у флорентийского герцога, он отмечает, что “стояли и с ним говорили в шляпах, а потом имел великие ригалы ${ }^{21}$ вин и цукров, как обыкновенно всем князьям от крови так чинят."22 Здесь подчеркивается, что Тосканский двор чтит не столь посольский ранг, сколько родовое достоинство и титул. Следя за информацией (видимо, газетной) о своих дипломатических вояжах, Куракин удовлетворенно записывает: “сперва, как приехал до Вены, уже давно о том писали, что приехал великой фамилии principe Kurakin.”23 Общаясь при Ганноверском дворе с имперскими принцами, он отмечал, что “давал им правую руку, токмо не всем.” ${ }^{24} \mathrm{O}$ трениях с А.А. Матвеевым во время Утрехтского конгресса Куракин заметил, что “Правда ему больший способ был - его характер [т.е. полномочия посла, тогда как Куракин был неофициальным представителем - Ю.Э.], а мне - порода моя и власное $^{25}$ имя, к тому ж и кредиту большего при дворе.” 26 Дипломатическая служба для Куракина не только служение государю и “патрии,” не только способ реализации карьеры, но и возможность прославления своего рода. Оценивая свою деятельность в Италии, князь позволил себе записать: "Истинно похвалюсь, что нации Московской никто чести и славы прежде моего бытия не принес. Правда, себе разоренье во иждивении том понес, однакож в честь и славу государства и патрии, имени своего, дому Caributoff Kurakina, князей наследственных литовских." ${ }^{27}$ В мировоззрении его, по словам А.Г.Тартаковского, “сложной и одаренной натуры,” воплощавшей в себе “в

\footnotetext{
19 А.Н. Котляров, Историография дворянства и ее место в развитии исторической науки в России (ХVIII в.) (Томск, 1990), 19.

${ }^{20}$ Архив кн. Ф.А.Куракина. Изд. под ред. М.И. Семевского и В.Н.Смольянинова. Т. 1-8 (М.-Саратов, 1890-1899) [Далее: Архив], 3: 195-196.

${ }^{21}$ подарки, подношения (итал.)

${ }^{22}$ Архив 1: 276; см. также: Шмурло, “Новый свидетель преобразований,” 192-193.

${ }^{23}$ Архив 3: 201.

${ }^{24}$ Киевская старина 12 (1884), 632.

${ }^{25}$ Собственное (польск.).

${ }^{26}$ Архив. 3: 314.

${ }^{27}$ Архив 3: 279.
} 
большей степени, чем другие люди его времени, тип личности новой переходной эпохи," ${ }^{28}$ смешались усвоенные в детстве ценности, связанные с местническим типом понимания родовой чести, и западноевропейские представления об аристократизме. Так, если на Москве Рюриковичу или Гедиминовичу еще недавно могли указать, что он “человек неродословный," поскольку его предки “захудали” (а при Петре вообще наступило время “случайных" личностей), то на Западе перед “потомком Ягеллонов,” занимавших королевские престолы в Польше, Швеции, Норвегии (как почтительно, хотя и не вполне точно о родне Куракина писал Сен-Симон) открывались двери монарших резиденций и аристократических домов. Перед “власным именем” и “кредитом при дворе” Куракина ничто был и официальный “характер” незнатного Матвеева.

На “российский компонент” аристократического самосознания Куракина оказывала влияние, вероятно, и своеобразная устная историческая традиция сохранявшаяся в его семье и известная по особенностям некоторых местнических дел его предков. Челобитная князя Ф.С. Куракина (двоюродного деда) в его деле с князем А.Н. Трубецким 1641 г. - единственный источник сведений о якобы принятом после бегства князя М.Курбского приговоре о понижении в местническом счете родственников “отъехавшего" к другому государю: “А как де, государь, князь Ондрей Курбской отъехал в Литву при деде твоем, государе нашем блаженныя памяти государе царе и великом князе Иване Васильевиче всея Руси, и после, государь, князь Ондрея отъезду дед твой государь наш [...] Иван Васильевич [...] приговорил - которого роду хоти хто меншой отъедет, и того роду и у большого отнять 12 мест: кому они были в версту, и тех указал государь быть двенадцатью местами меншим. И тот, государь, приговор в твоих государевых розрядах записан." 29 Ссылка на “государевы разряды” до сих пор не находит подтверждения ни в одной из ныне известных редакций разрядных книг. Уже тогда, похоже, она привела в замешательство ведущих дело разрядных дьяков. Официальный ответ на челобитную выдержан в несколько нарочито раздраженной тональности. Помянув сначала прегрешения дяди Ф.С. Куракина, сторонника кандидатуры на русский престол польского королевича Владислава в Смуту, Разрядный приказ выговаривал: “А что ты пишешь к нам в своей отписке про измену князя Андрея Курбского и про приговор, которые изменяют, что тою изменою своею многие месты теряют, и тебе было нам, великому государю, писать непригоже, прежних великих государей указы и приговоры нам ведомы [больше твоих вычетов] ${ }^{30}$ и знаем [мы, ково с кем ровнять и кому с кем быть]." ${ }^{31}$ Приказные бюрократы явно не смогли отыскать документ, о котором шла речь, но не решились и опровергнуть самый факт его существования (чем можно объяснить их раздраженный тон). Выделенные места чернового отпуска зачеркнуты и неясно, в каком виде беловик был отослан Куракину. Последний, заметим, отвечал не без яда ${ }^{32}:$ “Да ко мне ж, холопу твоему писало про князя Андрея Курбского, что

\footnotetext{
${ }^{28}$ А. Г. Тартаковский, Русская мемуаристика XVIII - первой половины XIX в. (М., 1991), 39.

${ }^{29}$ РГАДА. Ф.210. Оп.9. Ст. 157. Стп.1. Л.5.; А. И. Маркович, О местничестве (Киев. 1879), 472.477.

30 Зачеркнуто. (в квадратных скобках).

${ }^{31}$ РГАДА. Ф.210. Оп.9. Ст. 157. Стп.1. Л. 24.

${ }^{32}$ Князь Фёдор Семенович вообще, кажется, отличался упрямством и неуживчивостью на службе. Kosheleva, "Gediminacial rusijos bojarinu dumos sudetuje caru Aleksejaus ir Fiodoro valdymo metais," 7.
} 
было мне [...] про ваши государевы указы и приговоры писать к тебе, государю, непригоже. И мы, холопы твои, бьем челом и милости просим у тебя государя в отеческих делах и ссылаемся на ваши государевы указы и приговоры." 33 Ведь любое судебное дело можно вести не иначе, как опираясь на законодательные акты. Затем князь сообщает о источнике своей информации: “Мне, холопу твоему про ваши государевы указы и приговоры ведать было от ково - тебе государю известно, дед мой, князь Андрей Петрович, каков был в летех стар, и жил все при вашей государской милости, и про ваши государевы указы и приговоры все ведал." 34 Князь А.П. Куракин упоминался в разрядах как воевода уже с 1573 г., так что он был современником событий. ${ }^{35}$ Но обращение к этим сведениям не спасло внука от местнического поражения.

Интересно, что сословное самосознание французской аристократии, несмотря на иной исторический опыт и условия существования, иногда давало примеры внешне сходных форм протеста, причем именно Сен-Симон не раз оказывался в центре подобных конфликтов. Например, защищая права корпорации герцогов, он представил дофину целый трактат “об уничтожении остатков достоинства герцогов и пэров Франции как внутри, так и за пределами королевства." Материалы для трактата герцог собирал, как он сообщает, несколько лет как в архивных документах, так и в приватных беседах со старыми придворными, ${ }^{36}$ что напоминает вышеприведенную ссылку на рассказ А. П. Куракина. По назначению своему этот трактат, видимо, был близок к русским “местническим справочникам," хотя его форма, наверное, была совсем иной.

Сходные настроения продиктовали и следующую фразу Б.И. Куракина в его "Гистории": в правление Нарышкиных, по его словам, произошло “наибольшее начало падения первых фамилий, а особливо имя князей было смертельно возненавидено и уничтожено." 37

Принцип защиты интересов феодальной корпорации был понятен Куракину, поскольку являлся одним из краеугольных камней местничества. Тот же его двоюродный дед Ф.С. Куракин в 1633 г. просил записать в Разряде, что он и князь Н.И. Одоевский готовы быть с князем Д.М. Черкасским, но “будет которая их братья им, князю Миките и князю Федору отечеством в версту, а иные моложе их, а учнут вперед бити челом на боярина на князя [...] Черкасского, и не похотят с ним быти в товарищах, и им бы и родителем их в том бесчестьи и позору не было.“38 Так отдельным членам корпорации приходилось “подстраховываться” на случай неприятия их собратьями уровня “чести,” определенного данным назначением.

В центре сходного корпоративного конфликта не раз оказывался Сен-Симон. В 1703 г. “заместничали” герцогини с принцессами в связи с тем, что последние

\footnotetext{
33 Маркевич, О местничестве, 475.

34 РГАДА. Ф.210. ОП.9. Ст. 157. Стп.1. Л. 32. Ю. М. Эскин, Очерки истории местничества в России (М. 2009), 153-154.

35 Разрядная книга 1475-1598 г2. (М., 1966), 248. В 1575 г. был казнен его отец боярин князь П.А. Куракин. См. Р. Г. Скрынников, Царство террора (СПб. 1992), 496-497.

${ }^{36}$ Сен-Симон, Мемуары, 2: 511-515.

${ }^{37}$ Архив, 1: 64. В реальности, еще раз заметим, наследственный княжеский титул в местнических взаимоотношениях существенного значения не имел, и Куракин, видимо, проецирует на российское прошлое свои зарубежные впечатления.

${ }^{8}$ Книги разрядные по официальным оных спискам (СПб. 1853), 2: 547.
} 
решили препоручить им сбор пожертвований во время придворных церковных церемоний, сочтя, видимо, это не слишком почетным. Герцоги по инициативе Сен-Симона воспротивились, что рассердило Людовика XIV. Слова короля весьма напоминают высказывания русских царей в сходной ситуации. Король, как передает сам Сен-Симон, был недоволен, решив, что “я оставив службу, думаю лишь о том, кто выше кого, и со всеми подряд веду тяжбы, и угрожал заслать меня в такие дали, откуда я долго не мог бы ему докучать." 39 В личной беседе, правда, Сен-Симону удалось оправдаться, но весьма дорогой для его позиций ценой. Он заверял Людовика XIV, “что и я, и герцоги как нельзя более ему преданы, а также твердо убеждены, и я более чем кто-либо другой, в том, что поскольку наше достоинство проистекает из достоинства Его Величества, а жизни наши осенены его благодеяниями, то он, будучи королем и общим нашим благодетелем, остается полновластным хозяином достоинства нашего, каковое волен возвышать, унижать и вообе обходиться с ним как со своим собственным достоянием." ${ }^{\circ}$ Много лаконичнее та же мысль выражена у князя Ф.С. Куракина в вышеупомянутом деле: “честны мы, холопи твои, бываем по твоей государской милости и бесчестны бывали по твоему же государеву указу." ${ }^{11}$ Заметим, что французский аристократ находился в данном случае в более уязвимой позиции, чем русский. Понятие “честь” означало в России XVIXVII вв. сумму пожалованных монархом чинов, назначений и привилегий, необязательно наследственную (разрядные назначения воеводами, посольства, возведения в думные и московские чины и т.д.). Поэтому столь распространена, например, формула приговора: “честь и боярство отнять”. Или, например, боярин Е.И. Стрешнев, жалуясь на князя Ю.П. Буйносова-Ростовского, сообщал, что тот в челобитной на него писал о нем “без великия государския милости, без моей чести, без “боярина."” 42 В то же время сумма “честей” в процессе долговременного функционирования рода в московской разрядно-местнической системе перерастала в новое качество - в “отечество," отнять которое монарх уже был не в силах. Поэтому сын лишенного “чести и боярства" лица мог претендовать на положение, занимавшееся его предками. Именно термин “отечество” применялся для перевода и разъяснения западноевропейского понятия дворянского титула. Так, русский посол Г.И. Микулин, познакомившись при английском дворе с молодыми чешскими дворянами, писал о них: “Цесарские области Муравские земли князи, три брата, Рудольф, Жигимонт, Фридерик, а отечеством словут бароны." ${ }^{33}$ Русский княжеский титул тоже входил в круг понятий “отечества," хотя и не имел большого значения. Монархи никогда не отнимали и не жаловали этот титул; знатные иностранцы получали его лишь “переводом,” если имели любой собственный титул - мурзы, графы, баронеты и т.д.

В то же время западноевропейские монархи жаловали наследственные титулы, поэтому Сен-Симон и говорил об “источнике достоинства.” Однако он,

\footnotetext{
${ }^{39}$ Сен-Симон, Мемуары, 1: 176.

${ }^{40}$ Сен-Симон, Мемуары, 1: 179. (Разрядка моя - Ю.М.)

${ }^{41}$ Маркевич, О местничестве, 475. (Разрядка моя - Ю.М.)

${ }_{42}$ РГАДА. Ф. 210. Оп. 13. СТ. 272. Л. 426.

${ }^{43}$ Архив разнородных и преимущественно исторических сведений, изданный кн. М.А. Оболенским (М., 1845), Ч. 1. Связка IV. С. 27.
} 
конечно, гиперболизировал: несмотря на известное раболепие двора Людовика XIV, подобную декларацию общественное мнение (прежде всего те же герцоги) ему бы не простило. Королю, конечно, высказанное пришлось очень по душе: он благосклонно отвечал, что “это, мол, похвальные мысли и речи.” Но, желая оправдаться перед читателем, Сен-Симон разъясняет: король, “столь деспотичный и столь уязвимый в своем деспотизме,” все же был иногда “способен внять голосу разума," лишь бы убеждавший его “польстил его деспотическому самолюбию и сдобрил свою речь самым что ни на есть глубоким почтением,"44 а по сути - откровенной ложью и лестью. Старым французским аристократам времен Людовика XIII (чью эпоху Сен-Симон идеализировал) скорее бы пришлось по нраву известное высказывание князя Ф.С. Куракина: "Хоти ты, государь, нивисть кому велишь выдать или смертью казнить без вины, и в том твоя государева воля, а наказу и списков мне взять не мочно." ${ }^{45}$ Но СенСимону присущ иной менталитет, он был “молодым" (по русской местнической терминологии) герцогом. Титул пожаловал его отцу Людовик XIII, столь высоко оценивший заслуги своего пажа на охоте - любимом королевском времяпрепровождении. “Отечество” его действительно исходило от королевской милости, и в этом одна из причин многочисленных придворно-церемониальных конфликтов, столь заинтересованно им разыгранных и описанных. Кроме того, Сен-Симон осознал себя членом корпорации пэров, являвшейся высшей во Франции, но уже терявшей свои прерогативы. Отсюда - постоянная борьба за свое место внутри корпорации и за место корпорации внутри государственной системы. А.Д. Михайлов замечает о Сен-Симоне, что “его устраивала строгая иерархия, пронизывавшая систему сверху донизу - когда каждый знает свое место - и обязанности и права." ${ }^{46}$ Соблюдение прав личности аристократа было “краеугольным камнем его общественной и политической системы,” в рамках которой короли были лишь “первыми среди равных," а герцоги служили им не из выгоды, а из высших принципов, как “велят ему долг и честь." 47

Как же видоизменялось к концу XVII в. понимание “чести” в России? В него начали включаться элементы, которые можно воспринимать как личное достоинство, уже не вполне зависимое от монарших назначений и многовекового родового “отечества." Когда в 1668 г., за восемь лет до рождения Б.И. Куракина, с его дядей князем Г.С. Куракиным местничал князь П.И. Хованский, то в суровом приговоре последнему (формально смертная казнь, фактически - ссылка в свои вотчины) можно было увидеть необычные пассажи: “тою своею глупостью ты, князь Петр, Божию и ево великого государя полковому делу учинил поруху многую, и которым ратным людям от той твоей глупости [...] учинились какие порухи и истери, и за то тебе воздан будет ответ в день Страшнего Второго Христа пришествия." ${ }^{8}$ Эмоциональность стиля позволяет предположить авторство самого Алексея Михайловича. Главное же заключается в том, что поступок оценивается по-новому, на основе моральных категорий. Блюдя интересы своего рода, человек нарушил приказ - и за это его накажет

\footnotetext{
${ }^{44}$ Сен-Симон, Мемуары, 1: 186.

${ }^{45}$ РГАДА. Ф. 210. ОП. 9. Ст. 157. Стп. 1. Л. 52-53.

${ }^{46}$ Сен-Симон, Мемуары, 1: 27.

${ }^{47}$ Ibid., 27-29.

${ }^{48}$ РГАДА. Ф. 210. Оп. 15. Ст. 133. Л. 430.
} 
государство, монарх, но он чист перед своей корпорацией. Однако из-за интересов корпорации войско понесло потери, погибли люди - и личность даст за это ответ на Страшном суде. У того же князя Г.С.Куракина уже в 1658 г. возник конфликт в Новгороде с князем А.М. Солнцевым-Засекиным. Ситуация эта стала предметом конфиденциальной беседы Куракина с Алексеем Михайловичем. Царем “было говорено наедине о непочитанье ему от товарища его, от князя Ондрея Солнцова,” и предложена защита: “и будет ему [...] надобно оборон, и он бы [...] отписал на него к государю." 49 Князь вежливо отклонил государево предложение традиционно-местнических “форм воздействия," сказав: “на товарища де своево на князь Ондрея Солнцева к государю писати не станет, а учнет у [...] государя милости просить, как он [...] пресветлые очи увидит. И говорил он [...] с жалобою: Бог де ево судит, не знает де он [...] каких он, князь Ондрей, мер человек, ево де боярской добродетели и почитанья к нему, князь Ондрею было много."50 Таким образом, спор переносится в лично-моральную плоскость, что было по достоинству оценено и Солнцевым-Засекиным, понявшим неизбежность местнического поражения в суде с одним из знатнейших аристократов (на стороне которого и царское благоволение). Поэтому через месяц князь Г.С. Куракин “сказывал, товарищ ево [...] после государева указу перед ним, боярином, прощался." ${ }^{11}$ Эпизод этот иллюстрирует постепенный распад прежних ценностей незыблемого корпоративного понимания “чести," в которой, как в понятии, с конца XVII в. постепенно начинает превалировать значение нравственной категории. ${ }^{52}$

Б.И. Куракин - человек переходной эпохи, живший и старыми и новыми нормами. В 1708 г. по возвращении из Рима он впал в немилость (интригами Г.И. Головкина и В.В. Долгорукова); дошло до того, что Петр однажды публично обвинил его в том, что "я де не хочу служить в военной службе, а ищу де случая попасть в министерию” [посольство - Ю.Э.] и даже пригрозил виселицей. ${ }^{53}$ Когда же он, сильно поиздержавшись в посольствах, ${ }^{54}$ попросил о повышении в чине, Головкин заявил, что он - гвардии подполковник, посылается за границу в высших дипломатических рангах и получает соответствующее жалованье. Б.И.Куракина жестоко оскорбила эта откровенная отговорка: ведь было известно, что за участие в Полтавском бою он не был награжден, а на выдаваемое ему жалованье за границей в ранге посла жить было невозможно. “Всем тем дишкурсом, коротко сказать, что пробил мое сердце и привел меня в

\footnotetext{
${ }^{49}$ РГАДА. Ф. 27. Оп.1. Д.123. Л.1.

${ }^{50} \mathrm{Ibid}$.

${ }^{51}$ Ibid., Л. 3.

52 Л.А. Черная, “От идеи 'служения государю' к идее 'служения отечеству' в русской общественной мысли второй половины XVII-XVIII в.,” Общественная мысль: Исследования и публикации (М., 1989), 1: 41.

${ }^{53}$ Киевская старина 12 (1884), 628.

54 По словам Сен-Симона (Мемуары, 2: 354), Куракин был скуповат. Это особенно бросалось в глаза, наверное, при сравнении с его предшественником, князем В.Л. Долгоруким. Он задавал роскошные банкеты для парижской знати и буржуа и даже выставлял на улице оркестр и угощение для народа. Однако Куракин, несмотря на титул и родство с царем, был по французским “вельможным" меркам не столь уж богат, а для поддержания своего посольского ранга был вынужден продавать собственные деревни. Находясь в Англии даже на приглашение королевы Анны на карточную игру ему однажды пришлось "вежливо отговориться за неполною мошною." См.: Архив 1: 289-290; 4: 45.
} 
такое уничтожение, что будто я не достоин по своей природе всех этих чинов, что он упоминал, но как бы мне то причитал за диковинку или за находку [курсив наш - Ю.Э.]. И потом я, ни говоря ни слова, ушел от него с великою скрухою от всего сердца."55 Уязвлено было государственно-служебное, и кастовоаристократическое, и человеческое достоинство, т.е. “честь” и “отечество.” С ним разговаривали оскорбительно, не оценили его дипломатическую службу, подвергнуты сомнению даже его ранги, каковых, по его глубокому убеждению, он достоин просто “по природе своей," происхождению. Оживает и забытый местнический термин “находка," т.е. назначение более высокое, чем то, которое лицо определенной знатности могло получить, благодаря чему все потомки его могли претендовать на аналогичное. А.И. Заозерский отмечал, что высшие аристократы в петровскую эпоху, “лишенные возможности отстаивать родословный принцип при служебных назначениях, [...] крепко держались его в частных отношениях."56 Замечателен эпизод “чисто местнического” типа. На свадьбе царевича Алексея (Куракин был его дядей по материнской линии) произошел, по словам князя “случай некоторой [...].

Когда по веньчанье был чиновной стол, за которым сидят все принцы крови, так же из нас: граф Головкин канцлер, Брюс генерал и князь Трубецкой, я и князь Долгорукой, Лукин сын; когда начали садитца за стол, и, правда, дому тутошнего почтили меня по достоинству, но персоною самого царского величества посажен Яков Брюс; тогда я принужден был сам взять последнее место и ниже всех тех помянутых сидя, и нарочно являл лицо малконтент." 57

Вряд ли можно согласиться с А.И. Заозерским, говорившим, что царь просто захотел иметь рядом “интересного собеседника." ${ }^{8}$ Скорее налицо в очередной раз продемонстрированная Петром антипатия, не мешавшая использовать таланты князя, но препятствовавшая награждениям. Однако эпизод можно расшифровать и по традиционно-местнической схеме. Брюс - не выскочка, как Меншиков (на сидение “ниже” ему подобных Куракин бы и не обиделся: безродные фавориты - “в ином измерении”). Брюс - “знатный иностранец," происхождение (“отечество”) которого интересовавшийся генеалогией Куракин, возможно, представлял; в данном случае Брюс “заехал по иноземству” старую знать (терминология разрядных книг). Однако конец этой истории идет вразрез с прежней местнической традицией. “Теперь-то окончеваю то без всякой так остимы, что великой кредит свой утратил в ту свою бытность!" - продолжал князь, - “Однако ж могу себе причесть за счастье, что двора государева многие мне великое благодеяние являли, и соболезновали о таких моих нещастливых поступках." 59 В “своем кругу,” очевидно, аристократы оказали члену своей

\footnotetext{
${ }^{55}$ Архив 3: 307. (Подчеркнуто автором - Ю.М.)

${ }^{5}$ А.И. Заозерский, Фельдмаршал Б.П. Шереметев (М., 1989), 195. Хотя, конечно, Петра с Брюсом бесспорно связывал интерес к технике, артиллерии и пр.

57 Недовольное (франц.). Архив 3: 310-311.

$5^{8}$ Заозерский, Фельдмаршал Б.П. Шереметев. Полагаем также, что человек, чье общество ценили Сен-Симон в Париже и Болингброк в Лондоне (о последнем Куракин в 1710 г. сообщает, что СентДжон “ума человек великого, который мне больше всех явился в наш интерес,” Архив 4: 282), вряд ли принадлежал к скучным собеседникам.

${ }^{59}$ Архив 3: 310-311.
} 
корпорации моральную поддержку, хотя были далеки от открытого фрондирования. История эта весьма напоминает случаи, описанные у СенСимона, который призывал пэров отстаивать свои права. ${ }^{60}$

Включение служилого сословия в регулярную государственную систему с одновременным его нивелированием было одной из важных тенденций петровской внутренней политики. Политическое влияние уходило из рук аристократии в руки бюрократического аппарата. В “Пунктах” А.И. Остермана, в проекте “Табели о рангах” отмечал С.М. Троицкий, развивалась мысль, что любой человек, независимо от происхождения, может получить ранг благодаря верной службе. “Тем самым чины, приобретенные службой монарху, ставились выше привилегий, даваемых дворянским происхождением..”1 По самой природе своей консерваторы, аристократы, - считает А.И. Заозерский, - в обстановке ломки старых форм жизни обращались на Запад в поиске таких идейных образцов, которые помогли бы сохранению их социально-политического положения - и находили их в культуре стран, где аристократия сохраняла первенствующее положение (во Франции и Англии - отчасти формально, а в Польше - по-существу)." ${ }^{\prime 2}$ В то же время менее родовитые петровские посланцы за рубеж наоборот, негативно оценивают ограниченные монархии. ${ }^{63}$ Аристократы, включаясь в западноевропейский высший свет, мгновенно осваивают его ритуалы и фетиши - такие, как общий “политес,” геральдика, дуэльный кодекс, за которыми внедряется традиция неприкосновенности “благородной” личности. ${ }^{64}$ Восприятие было хорошо подготовлено внедрившимися элементами “полонизированной” культуры конца XVII в. Куракин не принадлежал к интимной “компании" Петра I, ${ }^{65}$ с ее наигранной фамильярностью, “шумством”; коробил его и демонстративный антиаристократизм, что Куракин не скрывает в описании святочных развлечений. Презрением дышит и описание буржуазной унылости амстердамской или гамбургской жизни, ${ }^{66}$ тогда как именно голландское культурное влияние всячески внедрялось Петром.

В то же время его коллега и соперник А.А. Матвеев в сочинениях своих с явным удовлетворением четырежды отмечает отсутствие местничества во Франции: “в доме королевском,” “в домах своих при визитах и при столах," “в ассамблеях или собраниях" и между военными, ${ }^{67}$ и трижды - в Англии. ${ }^{68}$ Матвеева, как подметил С.М. Троицкий, привлекали во французской государственности именно неограниченная монархия, развитый аппарат, строгая иерархия должностей, борьба со своевольством знати, внимание к

\footnotetext{
6о А.Н. Савин, “Местничество при дворе Людовика XIV,” Сборник статей, посвященных В.О. Ключевскому (М., 1909), 287.

${ }^{61}$ С.М. Троицкий, Русский абсолютизм и дворянство в ХVIII в. (М., 1974), 74.

${ }^{62}$ Заозерский, Фельдмаршал Б.П. Шереметев, 196-197.

${ }_{3}$ Троицкий, Русский абсолютизм и дворянство, бо.

64 Так, уже в 1707 г. у Куракина “блиско было до duellio” с двумя венецианскими дворянами (См.: Архив 1: 278); позднее он отмечает, что в Ганновере почему-то поединков “между кавалерами на всем свете больше быть невозможно” (Ibid., 230).

${ }^{65}$ Заозерский, Фельдмаршал Б.П. Шереметев, 200

${ }^{66}$ Ibid., 196-197, 206-209.

67 Русский дипломат во Франции. Записки Андрея Матвеева (Л., 1972), 192, 193, 198.

68 Троицкий, Русский абсолютизм и дворянство, 58; А.Н. Медушевский, Утверждение абсолютизма в России (М., 1994), 161.
} 
дворянской по составу гвардии, ${ }^{69}$ хотя он “несколько переоценил степень исчезновения местнических нравов." ${ }^{70}$ На самом деле местничества, схожего с российским, т.е. развитого в систему, пронизавшую государство и общество, нигде в Западной Европе больше не было. ${ }^{71}$ Люди с родословной Матвеева могли попасть при версальском дворе в ситуацию, с удовольствием описанную СенСимоном. ${ }^{72}$ Сам Куракин добавлял к своей фамилии “Корибут," что объясняло французам его происхождение, поскольку еще недавно на польском престоле сидел другой Гедиминович - Михаил Корибут-Вишневецкий. Люди, подобные Матвееву, и даже более знатные, для Куракина были представителями "домов самого низкого и убого шляхетства." ${ }^{3}$ Так же презирал эту новую знать бюрократического происхождения и Сен-Симон, писавший о “великих министрах” Людовика XIV, которые “выйдя из грязи, сочли, что на свете нет никого кроме них , и все перевернули вверх дном.”

А.Н. Котляров справедливо полагает, что Б.И. Куракина вполне можно назвать пионером не только идеологии, но и историографии русской аристократии. ${ }^{74}$.В плане-реестре исторических работ, которые князь собирался написать (“Какия надобно книги написать о своем государстве для памяти себе впредь") на первом месте стоит такое развернутое заглавие: “Всех старых чинов от боярина и по самой низкой чин и потом временные чины, как судей, воевод и других, которые временно себе имеют, а не вовсе, и также и двора государева и со всеми чинами, и кто которого дела в каком управлении." На втором же месте в плане читаем: "Всего государства городов, в которых бывают больших фамилий воеводами, в которых - малых или посредних, и которой город как построен, и которого году, и которых дукатства или принципства, или так простых."75 По мнению А.Н. Котлярова, “конкретная задача планировавшейся Куракиным книги заключалась в решении вопроса 'что надобно во все государство высоких чинов для управления,"” а остальные пункты обширной программы так же ставят целью подготовку административных реформ, хотя “за утилитарностью задач

\footnotetext{
69 Троицкий, Русский абсолютизм и дворянство, 55-57.

$7^{70}$ Отметим, что сведения о так называемом “местничестве” во Франции рубежа XVII-XVIII вв. базируются исключительно на упомянутой статье А.Н. Савина, которая отчасти ввела в заблуждение двух специалистов по истории русского правящего класса XVIII в. A.H. Медушевский, Утверждение абсолютизма в России, 156, даже делает вывод со ссылкой на ту же статью, что французская знать “широко этим (т.е. местничеством) пользовалась.” Однако работа Савина посвящена единственному источнику - мемуарам Сен-Симона, лица крайне нетипичного. Л.Я. Гинзбург, Saint-Simon. Mémoires (M., 1976), 15, писала, что даже в версальской среде, с ее сильнейшим развитием ритуального, этикетного мышления, стала анекдотичной его ожесточенная борьба за мельчайшие привилегии ритуального порядка. Вернее указание А.Н. Медушевского, (противоречащее его же суждению чуть выше) где он ссылаясь на А.А. Матвеева отмечает, что местничество во Франции начала XVIII в. “выступает как своего рода исключение.” (См.: Утверждение абсолютизма в России, 202).

${ }^{71}$ И. Хейзинга, Осень Средневековья (М., 1988), 47, 472.

$7^{2}$ Жена министра иностранных дел, маркиза де Торси, сына Кольбера, случайно села “выше” одной из родовитых герцогинь за королевским столом, что разгневало Людовика XIV. B конце концов де Торси пришлось письменно извиниться перед королем. Но отметим, что когда Людовик XIV пожелал, чтобы кто-нибудь сообщил Торси о его недовольстве, даже принцессы побаивались портить отношения с “худородным” министром (Сен-Симон, Мемуары, 1: 254-261).

${ }^{73}$ Архив 1: 64.

${ }^{74}$ Котляров, Историография дворянства, 20.

${ }^{75}$ Архив 3: 189.
} 
угадываются и историко-познавательные мотивы." Однако похоже, что мотивы эти превалировали, поскольку князь, постоянно находившийся за рубежом, по горло занятый дипломатической службой и пребывавший в натянутых отношениях со своим августейшим родственником вряд ли мог серьезно претендовать на творческое участие во внутренних преобразованиях. Интерес князя к историческим судьбам своего сословия был интеллектуальным, а отчасти - прикладным, причем не с “государственной," а с “сословной” точки зрения. Его заботило, как “от такого бедства соблюстись,” т.е. избежать очередной “напасти” со стороны государства. ${ }^{76}$ Недаром он не раз подчеркивает, что пишет не для всех “посполито персон, а тем, которым принадлежит, как принцам, графам и каждому шляхетству." 77 В изучении аристократии Куракина интересует не только роль “постоянных и временных чинов," былого суверенитета великих и удельных княжеств, где были “принципства” и “дукатства," в которых он видит истоки российской социальной истории. Занимает его и такая проблема: нужно ли соотносить происхождение воеводы с политическим и историческим значением города, в который воеводу назначают. Известно, что Куракин был знаком с проектом “пожизненных наместничеств" 1681 г.: он упомянут в “Ведении о главах" задуманного им исторического труда “О проекте Языкова, было быть государственным чинам.”79 Как дипломату, ему хорошо известна традиция присвоения номинальных (для посольства) наместнических титулов, отчасти зависевшая и от “отечества” назначаемого лица. Известно, что и Сен-Симон составлял проект фиксации числа титулованных родов, среди которых должно было быть 50 пэрских, причем король мог пожаловать пэрство роду, но не отнять. ${ }^{80}$ Был, вероятно, князь в курсе и многочисленных “прожектов” своего сослуживца по Лондону Ф.С. Салтыкова (лица одного с ним круга, ${ }^{81}$ к тому же свойственника - брата мужа его сестры Марии). Салтыков предлагал Петру I ввести номинальные наследственные “дучества," формально провозгласив таковыми несколько городов, и сделал ряд других предложений (о вводе герольдов, майората и т.д.) в основном по английскому образцу. ${ }^{82}$

От Салтыкова, прожектера (по словам Н.П. Павлова-Сильванского) довольно бездумного, Куракина отличает широта и историзм мышления. Его не удовлетворяет попытка механического переноса иностранной традиции, он стремится найти отечественные исторические и юридические прецеденты для повышения роли аристократии. ${ }^{83}$ Куракин, как уже отмечалось, изучает

\footnotetext{
${ }^{76}$ Как историк и мыслитель, Куракин, по мнению Л.В.Черепнина, Русская историография до ХІХ в. (М., 1957), 158-159, продвигался от провиденциализма к прагматизму; объяснение им истории как цепи “интриг” лиц и партий объективно обосновывало претензии дворянства на главенство в историческом процессе.

${ }^{77}$ Архив 1: 130.

${ }^{78}$ Котляров, Историография дворянства, 24. Иными словами, роль собственно чинов (“боярин”) и роль должностей (“воевода”).

79 Архив 1: 92.; М.Я. Волков, “Об отмене местничества в России,” История СССР 2 (1977), 55.

${ }^{80}$ Савин, “Местничество при дворе Людовика XIV,” 286.

${ }^{81}$ Салтыковы, по мнению Куракина, были “из доброго шляхетства," тогда как Лопухины, (род его первой жены) - “из шляхетства малого” (См.: Архив 1: 53, 55).

${ }^{82}$ Н.П. Павлов-Сильванский, Проекты реформ в записках современников Петра Великого (СПб., 1897), 25 .

${ }^{83}$ Несмотря на то, что А.Д. Меншиков - парвеню и фаворит, князь заинтересованно отмечает,
} 
положение высшего сословия во всех странах, где ему приходится бывать. В Венеции он описывает и феодальное землепользование, и степень зависимости крестьян от сеньоров, и роль аристократии в государственном управлении, причем выделяет “старую нобильту" и тех "нобилей," что “ныне понаделаны из купцов,” которые в отличие от земельной аристократии настроены против войны с Турцией, поскольку тогда “их торги преткнутся.” Характеристика остатков старой знати в венецианском сенате перекликается с известной его же оценкой знати в боярской думе при правлении Нарышкиных, когда “бояре первых домов [...] в консилии или полате только были спектакулями." ${ }_{4}$ Куракин явно игнорирует факт, который ему наверняка известен, что богатство “старой нобильты“ Венеции - торгового происхождения. Он убежден, что политические права должны принадлежать исключительно старой земельной аристократии. В Венеции, например, “прежде сего все была старая нобильта, с природы которые имели поживление [с] своих земель, а не с коммерции.” Ослабление ее привело якобы к тому, что Венеция “начала упадать, как прежде в богатстве, так и в потенции." 85 Упадок шведского дворянства имеет иное происхождение - его притесняет абсолютистское государство. Рассказывая о проводившейся шведским правительством редукции, в ходе которой значительная часть земли была отобрана короной, Куракин объясняет, что шведский король “во всем том владении он власной наследник, для того, что в шведах ни принцев, ни графов, ни баронов николи не бывало, только одна нобилта [...]. И всегда они власные судиты $^{86}$ до королей своих были." ${ }^{87}$ Тем самым Куракин хочет показать, что, поскольку Шведское государство сложилось не из отдельных суверенных княжеств, как Россия, то и его дворянство не может иметь таких же прав, как потомки удельных властителей. ${ }^{88}$ Права эти, по мысли его, у русской аристократии “anno preso forsa” (отобраны насильственно). Итак, монарх, с государством в их отношении к аристократии - по одну сторону баррикад, аристократия - по другую. “Знать о том надобно [т.е. о шведском “опыте” - Ю.Э.] для своего выводу, ежели коли случит, от такого бедства соблюстись.” ${ }^{89}$ Право на сопротивление законно потому что каждый шляхтич имеет “ауториты и супремат,"9о властвует над поддаными от своего наследствия (т.е. он, по мысли Куракина, государь в своем поместье); конечно, Куракин выдавал желаемое за действительное, причем на западном “материале," а главное потому, что “начало Всероссийское власно так, как республика Польская.” Таким образом, Российское

что он “учинен дуком Ингриею, сувраном в своем владетельстве.” См.: Киевская старина 11 (1884), 495 .

${ }^{84}$ Т.е. - зрителями (итал.) Архив 1: 64.

${ }^{85}$ Архив 3: 195.

${ }^{86}$ Собственные подданные (польск, итал.)

${ }^{87}$ Ibid., 202.

88 Куракин демонстрирует осведомленность в истории шведского дворянства, составлявшего одно сословие и делившегося только на дворян и рыцарей. Феодальная структура в Швеции не была развита как, например, в Англии. Описанная Куракиным “Большая редукция" лишила шведское дворянство к 1697 г. половины владений и толкнула лифляндское рыцарство к Петру I См.: История Швеции. Под ред. А.С. Кана (М., 1974), 115, 192-193, 235.

89 Архив 3: 202. М.А. Алпатов, Русская историческая мысль и Западная Европа. XVII-первая четверть XVIII в. (М., 1976), 213, подметил, что “отличительной чертой Куракина как дипломата и автора было умение за внешностью событий [...] видеть суть дела.”

90 Власть, право (итал., фр.) 
государство, в отличие от Шведского, образовалось из слившихся "принципств и дукатств,” как и Польское, но Речь Посполитая сохранила права и свободы высшего сословия. Куракин явно симпатизирует политическому устройству Польши, $^{91}$ но прямо в пользу его не высказывается. Как дипломат, он профессионально осведомлен о переживаемом этой страной кризисе, одна из причин которого - коллапс государственности, вызванный соперничеством магнатских группировок. Политический идеал вступает в противоречие с реальностью. Куракин убежден в “биологическом” превосходстве аристократии над простолюдинами и в том, что древняя аристократия не обязана своим происхождением монархии. ${ }^{92}$ Однако по его мнению, “добродетели," воспитанные поколениями знатных родов, приходят в упадок, и их представители, “уверенные, что все должны оказывать им особое поклонение, перестают о чем-либо мыслить, бросают науки, знание, добродетель и самоуважение." 93

С ним перекликается Сен-Симон, признававшийся, что взяться за перо его отчасти побудило поразившее его невежество аристократической молодежи: “До чего, например, удивительно слышать, как люди недоумевают [...] кто был отцом короля и в каком родстве наш государь с королем испанским? [...] Слыша такое, нетрудно вообразить, каковы представления говорящих об истоках только что минувшего царствования [...] и какие потемки царят в их головах во всем, что относится ко временам более отдаленным. Вот они, следствия невежественного воспитания и вихря светской жизни, которые впрочем легко исправить беседою и чтением." ${ }^{44}$ И в этом Куракин с ним согласен: “Надо найти средство удержать знатные роды на должной высоте и не дать упасть их репутации." 95 Подобные взгляды формировались и зарубежными учителями русских аристократов. Так, венецианский профессор граф Ф. Дамиани, в выданном Куракину дипломе указывал, что стремился показать своим ученикам что “Знаменитые великодушием и благородством герои не только своим высоким рождением озаряли свой род, но и силой своих знаний приобретали бессмертие." 96 Куракин познакомился за рубежом и с какими-то (возможно, французскими или итальянскими) сочинениями, авторы которых, по его словам, “нетитулованные дворяне и простые люди, как например, ученые юриспруденты, убеждены, что княжеские и знатные фамилии не представляют ничего особенного." 97 А.Н. Котляров отмечает: “В странах Западной Европы, прежде всего во Франции, история средневековой знати с первых десятилетий XVIII в. стала объектом острейших столкновений между идеологами аристократии и 'III сословия."'98

\footnotetext{
${ }^{11}$ В 1730 г., в эпоху активного дворянского политического творчества в одном из проектов, подписанном и сыном Б.И. Куракина князем А.Б. Куракиным, появляется предложение “сделать различие между старым и новым шляхетством,” как это практикуется в других государствах. См.: Г.А. Протасов, “Дворянские проекты 1730 г. Источниковедческое изучение,” Источниковедческие работы 2 (1971), 93.

$9^{2}$ Котляров, Историография дворянства, 21.

93 Архив 4: 115-116.

${ }^{94}$ Сен-Симон, Мемуары, 1: 52.

${ }_{95}^{95}$ Архи 4: 115-116; С.О. Шмидт, Становление российского самодержавства (М. 1973), 303.

${ }^{96}$ Архив 4: 79.

${ }^{97}$ Ibid., 115-116.

${ }^{98}$ Котляров, Историография дворянства, 18.
} 
Собиравшийся, как видно, включится в дискуссию, Куракин неоднократно подчеркивает, что пишет для избранных, а само писание подобных мемуаров “это обычай всех как высших, так и середних и самых шляхетных персон, [...] понеже и я тому воспоследовал." 99 Одну из двух задуманных книг с целью “наставления" аристократии он полагал обратить ко всему высшему сословию России: “обо всем этом мы будем писать только для нашей страны, обычаи которой нам хорошо знакомы." ${ }^{\text {”оо }}$ Вторая книга замышлялась как “наставление моим наследникам, как сыну, так и всей моей семье,” “о том, как следует вести себя с коронованными особами и лицами, занимающими высокие должности [...] а также с [...] низшими [...] что необходимо для вновь вступающего в общество [...] чего там надо искать [...].”101 Эти сочинения, вероятно, могли быть созданы по уже существовавшим образцам жанров, известным Куракину. Он, видимо, полагал, что лишь просвещенная аристократия, в совершенстве владеющая информацией о своем историческом прошлом и осознающая себя его законным преемником, признанным иными сословиями, сможет отстаивать свои права, и книги его должны были служить этой цели.

Сопротивление натиску государства, которое берет на себя право распоряжения личностью уже не только в сфере служебной, карьерной, но и в частной и имущественной, сквозит в описанном Куракиным инциденте, который А.И. Заозерский, вслед за издателем Архива кн. Ф.А. Куракина В.Н. Смольяниновым характеризует как пример “отстаивания родословного принципа в частных отношениях.” ${ }^{102}$ Князь негодовал на свою невестку, выдавшую дочь за А.П. Апраксина, хотя жених был племянником царицы Марфы Матвеевны. Но что более всего возмущает Б.И. Куракина? Невестка его, княгиня М. Д. Куракина,

“фамилии своей уничтоженье великое сделала, что за так низкую фамилию выдала; второе, что все так деревни [в приданное - Ю.Э.] вдруг отдала, то паче всего непорядочно учинила. А ко мне в том противность тем показала, что преже того времени ничего об том не объявила."103

Дело, на наш взгляд, было в том, что Борис Иванович тогда являлся старшим в роду (Михаил, отец невесты и его старший брат, умер в 1695 г.), но брак был заключен втайне от него, “без всякого совета.” 104 Неожиданная потеря немалой части вотчин, ушедших из-под контроля главы рода (100о дворов!), тоже была ударом. Недоволен князь был, возможно, и тем, что недвижимым имуществом распорядилась женщина, что было внове. ${ }^{105}$ А через “родословные” границы

\footnotetext{
99 Архив 1: 244; Шмурло, “Новый свидетель преобразований,” 200.

${ }^{100}$ Архив 4: 116. О том, что роль автора в историческом труде - это роль “наставника”, писал и СенСимон (Мемуары, 1: 4-5).

${ }^{101}$ Архив 1: 116-117.

102 Заозерский, Фельдмаршал Б.П. Шереметев, 195; Архив 4: 473.

${ }^{103}$ Архив 4: 263.

104 В 1699 г. Куракина также возмутило, что в его отсутствие опекун младшего брата Ивана, влиятельнейший вельможа князь П.И. Прозоровский женил Ивана на дочери Т.Н. Стрешнева (См.: Архив 1: 258).

${ }^{105}$ В петровские времена “женщине начало возвращаться право распоряжения недвижимостью.” См.: М.К. Цатурова, Русское семейное право XVI-XVIII вв. (М., 1991), 40.
} 
приходилось переступать: позднее, в 1718-1720 гг., едва не состоялся брак дочери Б.И.Куракина с сыном Г.И. Головкина “фамилии” столь же “низкой” что и Апраксины) и расстроился, судя по всему, лишь по семейным и финансовым причинам. $^{106}$ За браком Апраксина бесспорно, стояла царская воля: Петр I благоволил к ним, а все браки своего окружения строго контролировал. Государственный аппарат в тот период (в лице самого монарха или чиновников какого-либо учреждения) брал на себя функции, бывшие ранее прерогативой корпорации, которая в XVI-XVII вв. требовала наказания лица, принявшего более низкое назначение, чем ему положено “по отечеству." В “Табели о рангах" подобный казус находит иное решение: "Кто выше своего ранга будет себе почести требовать, или сам место возьмет выше данного ему ранга, тому за каждый случай платить штрафу [...]. Равной же штраф и тому следует, кто ниже своего рангу место уступит, чего надлежит фискалам прилежно смотреть." ${ }^{107}$ Тем самым декларируется отрицание “чести” вне чина, ответственность за сохранение которой тоже возлагается на государство. Любопытно, что в упомянутом выше инциденте с младшими Кольберами блюстителем аристократической чести выступает не корпорация герцогов, а король, деспотически отрицающий самостоятельность подданных в вопросе фамильной чести. $^{108}$

B предверии XVIII столетия идея “служения государю” уступает в России место идее “служения общему благу,” “общей пользе.” В подобных воззрениях были воспитаны и “птенцы гнезда петрова," в массе своей люди скромного происхождения, вполне довольствовавшиеся тем уровнем “чести," который предоставляла им “Табель о рангах" и рассматривавшие “отечество” как досадный анахронизм. Но в построенную из этих “винтиков” бюрократическую машину не вполне вписывалась независимая в суждених и инициативе личность, тем более если своим происхождением и воспитанием она являла как бы непрерывность отечественного исторического процесса. Антиолигархическая и антиаристократическая в значительной степени направленность абсолютизма известна. "Равность” в ничтожестве перед государством подчеркивается и демонстративным включением в бюрократическую систему сакральной личности государя. Он остается “помазанником Божьим,” но при этом продвигающегося по службе от низших чинов. Прежняя схема “народ служит царю, царь служит Богу” сменяется схемой “царь и народ служат Отечеству," “общему благу,” ${ }^{109}$ т. е. государству. Отныне прежние корпоративные формы протеста немыслимы, поскольку личности разделены рангами и только рангам оказывается почтение.

Абсолютистское правление Людовика XIV, по словам Сен-Симона, "целиком переменившее облик королевства,” породило в тот же период ситуации, внешне сходные с российскими местническими (несмотря на всю разницу в социальном, политическом, культурном развитии двух стран). Ранее “вольные” феодальные личности, теснимые “новыми людьми” и новыми бюрократическими

\footnotetext{
106 Приданое невесты должны были составлять вотчины, бывшие приданым ее матери, но враждовавшая с мужем княгиня Куракина этому противилась (Архив, 2: 395-411).

${ }^{107}$ Российское законодательство X-ХХ вв. (М., 1986), 4: 62.

108 "Культ этикета, церемониального формализма король превратил в политический факт, в средство утверждения абсолютной власти” - замечает Л.Я. Гинзбург (Saint-Simon. Mémoires, 15).

109 Черная, “От идеи ‘служения государю’ к идее 'служения отечеству,” 41, 42, 43.
} 
структурами (по мнению аристократии, "все перевернувшими вверх дном"), пытались оказывать сопротивление, хотя это уже никак не отражалось на возможности занятия реальных административных или военных должностей. В России теряющая позиции аристократия, пытаясь заново осмыслить свое место в перестраивающейся структуре, говорит о своем “принципальстве,” которое не менее законно, чем “супремат” государя. Б.И. Куракин символизирует переход к новым отношениям с государством - от местничества, умершего несколько десятилетий назад, к еще не родившейся “дворянской фронде.” Взо Вглды Б.И. Куракина и Сен-Симона, внешне столь архаичные, таили и иной смысл, поскольку отстаивали суверенитет личности, пусть только “аристократической,” и принципы политического достоинства, хотя и только одной социальной группы. Поэтому, как нам представляется, небезынтересно вспомнить о беседах представителей двух столь разных миров, одинаково отчасти “невостребованных" своими эпохами и общественными системами, двух людей Средневековья на пороге века Просвещения.

\footnotetext{
${ }^{110}$ Вскоре после смерти Куракина расцвело политико-законодательное творчество дворянства эпохи “Верховного Тайного совета." Насколько можно судить по памятникам этого творчества, оно не достигало интеллектуального уровня Куракина. Цельной программы не было даже у князя Д.М. Голицына, аристократического лидера. См.: Г.А. Протасов, “Существовал ли 'политический план’ Д.М. Голицына?” Источниковедческие работы 3 (1973), 93. В литературе обращалось внимание на Куракина как предшественника “верховников” и князя М. Щербатова. См., напр.: С.Л. Пештич, Русская историография XVIII в. (Л.,1961), 1: 113.
} 